\title{
Determining Morphological Traits for Selecting Wheat (Triticum Aestivum L.) with Improved Early- Season Forage Production
}

\author{
D.P. Malinowskia , J.C. Rudd ${ }^{b}$, W. E. Pinchak ${ }^{a}$, and J. Baker ${ }^{b}$ \\ aTexas Agrilife Research, POB 1658, Vernon, TX 76385, USA. \\ bTexas AgriLife Research, 6500 Amarillo Blvd W, Amarillo, TX 79106, USA. \\ dmalinow@ag.tamu.edu
}

\begin{abstract}
Winter wheat (Triticum aestivum L.) is the major annual crop in the Southern Great Plains of the USA grown as dual-purpose (forage and grain) crop. Wheat breeding has focused on maximizing grain yield and tolerance to abiotic and biotic stresses. Because of a lack of clearly defined selection criteria for breeding forage-type wheat, breeders usually rely on very laborious means to measure forage quantity and quality or they use imprecise visual estimates to quantify forage production. In a series of experiments conducted at Vernon, TX during 20032005, we determined correlations between selected morphological traits and the early-season forage DM yield in a range of wheat breeding lines and commercial cultivars evaluated by the Wheat Breeding Program of Texas A\&M AgriLife Research. Early-season forage DM yield was highly correlated with tiller number, leaf length and width, and inversely correlated with specific leaf weight. Environmental variables modified the responses. A number of wheat breeding lines and cultivars had combined three out of the four evaluated morphological traits, including Abilene Ag Exp., Cutter, Fannin, HG-9, Duster, TAM 110, TX01M5009, TX01V6016, TX03M1179, TX04M410009, and Weather master 135. These cultivars/breeding lines have been recommended for dualpurpose use; thus, the morphological traits evaluated in our studies were desirable for selection of wheat with improved forage productivity.
\end{abstract}

Key words: Forage, Morphological traits, Wheat

Abbreviations: DM, dry matter; RGR, relative growth rate; SLA, specific leaf area; SLW, specific leaf weight; TXE, Texas Elite Trial; UVT, Uniform Wheat Variety Trial

\section{Introduction}

Winter wheat (Triticum aestivum L.) is the predominant commodity in the Southern Great Plains of USA, sown on $10 \mathrm{M}$ ha each year. It is often used as dual-purpose (forage and grain) crop for grazing stocker cattle (Bos spp.) and grain production (Pinchak et al., 1996; Hossain et al., 2004). Wheat forage has a high nutritional value capable of producing weight gains greater than $1.4 \mathrm{~kg} \mathrm{~d}^{-1}$ (Mack own et al., 2008). Grazing cattle on wheat forage is practiced from early winter (late November) until development of the first hollow stem, which usually occurs in early March in dual-purpose systems or through May in graze-out systems.

Historically, wheat breeding research has focused mainly on maximizing grain yield and tolerance to abiotic (drought, heat) and biotic (insects, pathogens) stresses (Lantican et al., 2005). Development of dual-purpose or forage-type wheat cultivars was not addressed until late 1980's (Rajaram and Hettel, 1995). The early research indicated that selection requirements for improved forage production might be highly specific to the target environment and management and should involve traits like early-season forage production, grain recovery potential, and reduced awns (Pfeiffer, 1992). Although grain yield potential of modern cultivars is higher than older cultivars, breeding progress for forage production, forage quality, and tolerance to grazing has been very limited (Kim et al., 2016). Texas A\&M University System has released only three awn less cultivars bred primarily for grazing: Lockett, TAM 401, and TAM 204 (Rudd et al., 2012). In addition, two dual-purpose wheat cultivars have been released: TAM 202 (Worrall et al., 1995) and TAM 112 (Rudd et al., 2014). Because of a lack of clearly defined selection criteria for breeding forage-type wheat, breeders usually rely on forage quantity and quality 
during the fall-spring growing season as selection tools (Krenzer et al., 1992). Such an approach may not be the most appropriate because high grain yield and high forage yield traits are not always correlated (Atkins et al., 1969; Ud-Din et al., 1993).

The objective of this study was to determine morphological traits as tools for selection of wheat cultivars with improved early-season forage productivity based on commercial cultivars and breeding lines evaluated by the Wheat Breeding Program of Texas A\&M AgriLife Research (TAM Wheat Breeding Program) for high grain production and tolerance to insects, diseases, and drought.

\section{MATERIALS AND METHODS}

\section{Description of Field Experiments}

During 2003-2006, a series of experiments evaluating winter wheat breeding lines and cultivars were conducted

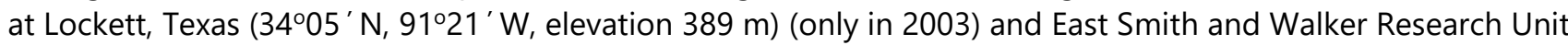
near Vernon, Texas $\left(34^{\circ} 03^{\prime} \mathrm{N}, 9^{\circ} 14^{\prime} \mathrm{W}\right.$, elevation $\left.378 \mathrm{~m}\right)$. Each year, the TAM Wheat Breeding Program evaluates a number of wheat breeding lines and cultivars across the state for various traits, including insect and disease resistance, drought tolerance, and grain production. The evaluation studies are coordinated and implemented by numerous Texas A\&M AgriLife Research and Extension faculty and staff. The evaluated wheat entries are grouped into a Uniform Wheat Variety Trial (UVT), consisting of released cultivars, and the Texas Elite Trial (TXE), which consists of advanced experimental breeding lines developed by the TAM Wheat Breeding Program. Each of the trials consists of 36-40 wheat entries that vary by region and change each growing season based on the breeding program objectives. If an experimental wheat breeding line was officially released after the study was conducted, the cultivar name is shown in parenthesis after the experimental designation.

At the Smith and Walker Research Unit, two experiments were planted in October each year on Rotan Clay Loam [fine, mixed, super active, Thermic Pachic Paleustolls] (Raushel, 2011). Experiment I consisted of 40 wheat breeding lines (TXE collection) and 40 wheat cultivars (UVT collection) and was a part of the TAM Wheat Breeding Program state-wide evaluation test. Experiment II consisted of 25-28, depending on year, wheat entries selected from the TXE and UVT collections based on contrasting characteristics, i.e., tiller number, early-season forage dry matter (DM) production, leaf morphology, and grain yield. These forage characteristics were determined on the TXE and UVT collections during a preliminary study conducted at Chillicothe, TX $\left(34^{\circ} 11^{\prime} \mathrm{N}, 9^{\circ} 31^{\prime} \mathrm{W}\right.$, elevation $442 \mathrm{~m}$ ) in 2002 (data not presented). Pre-planting fertilization of $34 \mathrm{~kg} \mathrm{ha}^{-1} \mathrm{~N}, 56 \mathrm{~kg} \mathrm{ha}^{-1} \mathrm{P}_{2} \mathrm{O}_{5}$, and 29 $\mathrm{kg} \mathrm{ha}^{-1} \mathrm{~K}_{2} \mathrm{O}$ was applied each season. Wheat entries were planted in a tilled seedbed with a precision planter (Wintersteiger, Salt Lake City, Utah) at a seeding rate of 250 seeds $\mathrm{m}^{-2}$. Plot size was 1.5 by $4.5 \mathrm{~m}$. Experiments at this location were not irrigated. In October 2003 only, the experiment with TXE and UVT collections was planted at Lockett on Miles fine sandy loam [fine-loamy, mixed, Thermic Udic Paleustalfs (Raushel, 2011)]. The reasons for choosing a different location with irrigation capability were severe drought conditions during the whole 2003 and predicted drought extending into 2004. Due to severe precipitation deficit, the experiment was irrigated with a sprinkle-type irrigation system at the equivalent of 2 inch precipitation once a month during October-December.

\section{Forage DM Yield and Plant Morphological Measurements}

To determine early-season (early December) forage production, a sample of wheat forage was harvested to the ground level from an area of $0.5 \mathrm{~m}^{2}$ located in the middle of each plot on December 10 ( \pm 3 days) each year. Forage samples were oven dried at $60^{\circ} \mathrm{C}$ until no changes in weight were detected. Samples were weighed to determine DM. Leaf length was measured with a ruler on 5 randomly selected leaves from each plot. Leaf area was measured on the same leaves with a LI-COR leaf area meter (LI-COR Biosciences, Lincoln, Nebraska, USA). Leaf width was calculated from leaf area and length measurements. After measurements, the 5 leaves were oven dried at $60^{\circ} \mathrm{C} \mathrm{F}$ until no changes in weight were detected and weighed to determine DM. Specific leaf weight $(\mathrm{SLW})$ was calculated as a ratio between leaf DM $(\mathrm{g})$ and leaf area $\left(\mathrm{cm}^{2}\right)$. Tiller number was determined at the 
time of forage sampling from plants grown in two neighboring rows on $0.3 \mathrm{~m}$ distance in each row and recalculated on $0.5 \mathrm{~m}^{2}$ basis.

\section{Statistical Analysis}

The experiments were set up as completely randomized designs and repeated during three growing seasons (October-March) in 2003-2006. In each experiment, treatments were wheat entries replicated three times. Statistical analyses were performed separately for each growing season of Experiment I and II because evaluated wheat entries varied each season in accordance with the objectives of the TAM Wheat Breeding Program. Data for early forage DM production, tiller number, leaf length, leaf width, and SLW were analyzed using Procedure Mixed (SAS Institute, 1999) (Table 1). Wheat entries were considered fixed effects, whereas replications were considered random effects in the analysis of variance (ANOVA). Significance of means was declared at $P=0.05$. Correlation and stepwise regression analyses of early forage DM with wheat morphological traits (tiller number, leaf length, leaf width, and SLW) were performed using the CORR Procedure and REG Procedure of the SAS software (SAS Institute, 1999). All variables left in the model of the stepwise REG procedure were significant at the $\mathrm{P}=0.15$.

Table 1. The ANOVA results for the randomized, complete block design in Experiment I and II during 2003-2005 growing seasons.

Source of variation

\begin{tabular}{|c|c|c|c|c|}
\hline \multirow{2}{*}{$\begin{array}{l}\text { Forage } \\
\text { variable }\end{array}$} & \multirow[t]{2}{*}{ Growing season } & \multicolumn{2}{|l|}{ Experiment I } & \multirow{2}{*}{$\begin{array}{l}\text { Experiment II } \\
\text { Wheat entry }\end{array}$} \\
\hline & & TXE (exp. lines) & UVT (cultivars) & \\
\hline & & $P>F$ & & \\
\hline \multirow[t]{3}{*}{ Early-season forage DM } & $2003-2004$ & 0.3859 & 0.0835 & 0.0006 \\
\hline & $2004-2005$ & 0.1140 & 0.0617 & 0.5448 \\
\hline & $2005-2006$ & 0.0037 & 0.0971 & 0.0715 \\
\hline \multirow[t]{3}{*}{ Tiller number } & $2003-2004$ & 0.1242 & 0.4775 & 0.0290 \\
\hline & $2004-2005$ & 0.0017 & 0.0429 & 0.0055 \\
\hline & $2005-2006$ & 0.0718 & 0.0384 & 0.0022 \\
\hline \multirow[t]{3}{*}{ Leaf length } & $2003-2004$ & 0.0002 & 0.0011 & 0.0016 \\
\hline & $2004-2005$ & 0.0067 & 0.0066 & 0.1554 \\
\hline & $2005-2006$ & $<0.0001$ & 0.0027 & 0.0046 \\
\hline Leaf width & $2003-2004$ & $<0.0001$ & $<0.0001$ & 0.4471 \\
\hline
\end{tabular}




$\begin{array}{llll}2004-2005 & 0.0008 & 0.0075 & 0.0025 \\ 2005-2006 & <0.0001 & 0.0071 & 0.8347 \\ & & & \\ 2003-2004 & 0.0006 & 0.0642 & 0.1130 \\ 2004-2005 & 0.0021 & 0.0237 & 0.0344 \\ 2005-2006 & 0.0048 & 0.0161 & 0.0020\end{array}$

\section{RESULTS AND DISCUSSION}

\section{Weather Patterns}

Severe soil moisture deficits during the early growing season (September-December) occurred in 2003 and 2005 (Fig. 1). The long-term average annual precipitation for the experimental location is $711 \mathrm{~mm}$. During the first 4 months of wheat growth (September-December), precipitation reached only 21\% and $49 \%$ of the long-term average amount (225 mm) in 2003 and 2005, respectively. In contrast, precipitation amount during SeptemberDecember 2004 was 37\% higher than the long-term average precipitation, but most of the rainfall occurred during November. The severe soil moisture deficit conditions during wheat establishment and early growth were coupled with higher than normal temperatures. For the months September-December, average temperature was higher by $1.6^{\circ} \mathrm{C}$ in 2003 and $1.2^{\circ} \mathrm{C}$ in 2004 and 2005 . 

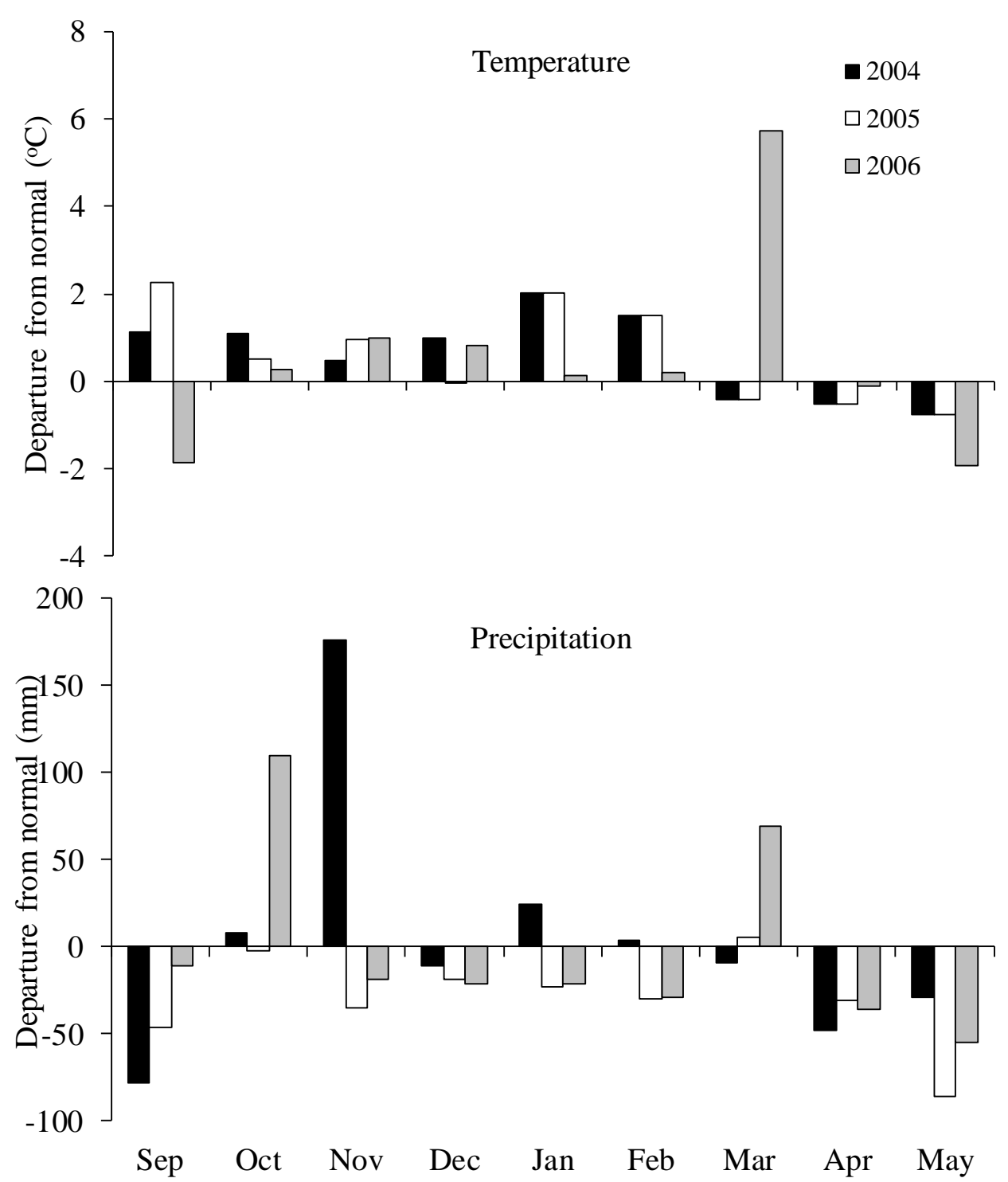

Fig. 1. Monthly temperature and precipitation departure from long-term average values at Vernon, TX for 20032004, 2004-2005, and 2005-2006 growing seasons (September-May).

\section{Differences in early-Season Forage Production among Experimental Wheat Breeding Lines and Cultivars}

Early-season forage production in winter wheat is determined by genetic potential, management, and environmental factors (Krenzer et al., 1992). Results of our studies showed a broad variability among wheat breeding lines and commercial cultivars for early-season forage production and correlated morphological traits. Under supplemental irrigation in Experiment I during 2003 growing season, breeding lines TX01V6334 and TX01V6016 produced greater early-season forage DM yield $\left(5501-6039 \mathrm{~kg} \mathrm{ha}^{-1}\right)$ than lines TX01D3218, TX01D3472, TX01U2723, TX01U2699, TX01V5314 (TAM 203), TX00D1390, TAMW-101, TAM 111, and TX01U2733 (2979-3876 kg ha-1) in the TXE collection, while the other lines produced an intermediate early-season forage DM yield (Fig. 2). Among commercial cultivars of the UVT collection (Fig. 3), greater early-season forage DM yield was produced by Overly, Coronado, Fannin, TAM 303, OK 102, TAM 202, 2174, and Jagelene (5064-6795 $\mathrm{kg} \mathrm{ha}^{-1}$ ) than TAM 112, TAM 111, TAM 110, 2145, TAM 107, Wintex, Intrada, TAM 110 CL, AP01T3131, OK 101, Weather master 135, Cutter, and Thunderbolt (3612-4119 $\left.\mathrm{kg} \mathrm{ha}^{-1}\right)$. Under rainfed conditions in 2004 growing season, breeding lines TX03M1179 and TX02V7426 produced greater early-season forage DM yield (1624 and 
$1306 \mathrm{~kg} \mathrm{ha}^{-1}$, respectively) than lines TX02V7937, TX02D5813, TX03M1016, and TX02D5797 (695-822 kg ha-1), with the other lines being intermediate (Fig. 2).

Wheat cultivars Overly, Cisco, Jagelene, and Doans had greater early-season forage DM yield (1173-1327 kg ha$\left.{ }^{1}\right)$ than Endurance, Thunderbolt, and TAM $202\left(671-725 \mathrm{~kg} \mathrm{ha}^{-1}\right)$, with other cultivars having an intermediate forage DM yield (Fig. 3). Under rainfed conditions in 2005 growing season, breeding lines TX01A7340, TX04M410009, and TX03A0123 had the greatest early-season forage DM yield (2285-2672 kg ha-1) and the line TX03V77023 had the least forage DM yield (1219 $\left.\mathrm{kg} \mathrm{ha}^{-1}\right)$. Other breeding lines in the TXE collection had an intermediate early-season forage DM yield. In the UVT collection (Fig. 3), the cultivars OK01307 and AP03T6115 produced greater early-season forage DM yield (2327 and $2316 \mathrm{~kg} \mathrm{ha}^{-1}$, respectively) than cultivars Guymon, Coronado, Neosho, and AP03T6126 (1219-1669 kg ha-1), while the other cultivars were intermediate.

In Experiment II, early-season forage DM yield varied among wheat entries each growing season (Fig. 4). In 2003, the breeding line TX97V5304 and cultivar OK 101 produced higher early-season forage DM yield (938 and 721 $\mathrm{kg} \mathrm{ha}^{-1}$, respectively) than the other wheat entries, while 2145, TX97D5088, Lockett, TAM 110, and TX01M5008 had the least early-season forage DM yield (314-399 kg ha-1). During 2004 growing season, early-season forage DM yield was less variable, with the cultivars HG-9 and OK 101 producing more early-season forage DM yield (876 and $874 \mathrm{~kg} \mathrm{ha}^{-1}$, respectively) than lines TX01U2598, TAM 303, and TX00D1390 (568-606 kg ha-1). During the 2005 growing season, wheat entries TX00V1117, Fannin, and OK 101 had greater early-season forage DM yield (1967-2021 kg ha-1) than TAM 303, TX00D1390, HG-9, Overley, and TAM 110 (1049-1205 kg ha-1).

Majority of the wheat entries evaluated in our studies were developed to maximize grain yield, a trait that is usually not correlated with forage DM yield (Krenzer et al., 1996). Several cultivars (i.e., Lockett, HG-9, 2174, Coronado, Cutter, Dumas, Fannin, OK 101, TAM 202, TX01M5009, Endurance) have been recommended for dualpurpose use or graze-out systems in the Southern Great Plains (Worrall et al., 1995; Bean et al., 2005). The cultivar rank for early-season forage DM productivity varied with environmental conditions each season in our studies. The best early-season forage producers were experimental lines TX00V1117, TX01V6334, TX01V6016, TX03M1179, TX01A7340, TX01M410009, and TX97V5304, and cultivars Overly, Coronado, Cisco, OK01307, AP03T6115, Jagger, HG-9, OK 101, and Fannin. The results agree with breeding objectives for improved forage productivity of these breeding lines and cultivars (Worrall et al., 1995; Bean, 2006; Edwards et al., 2008). 

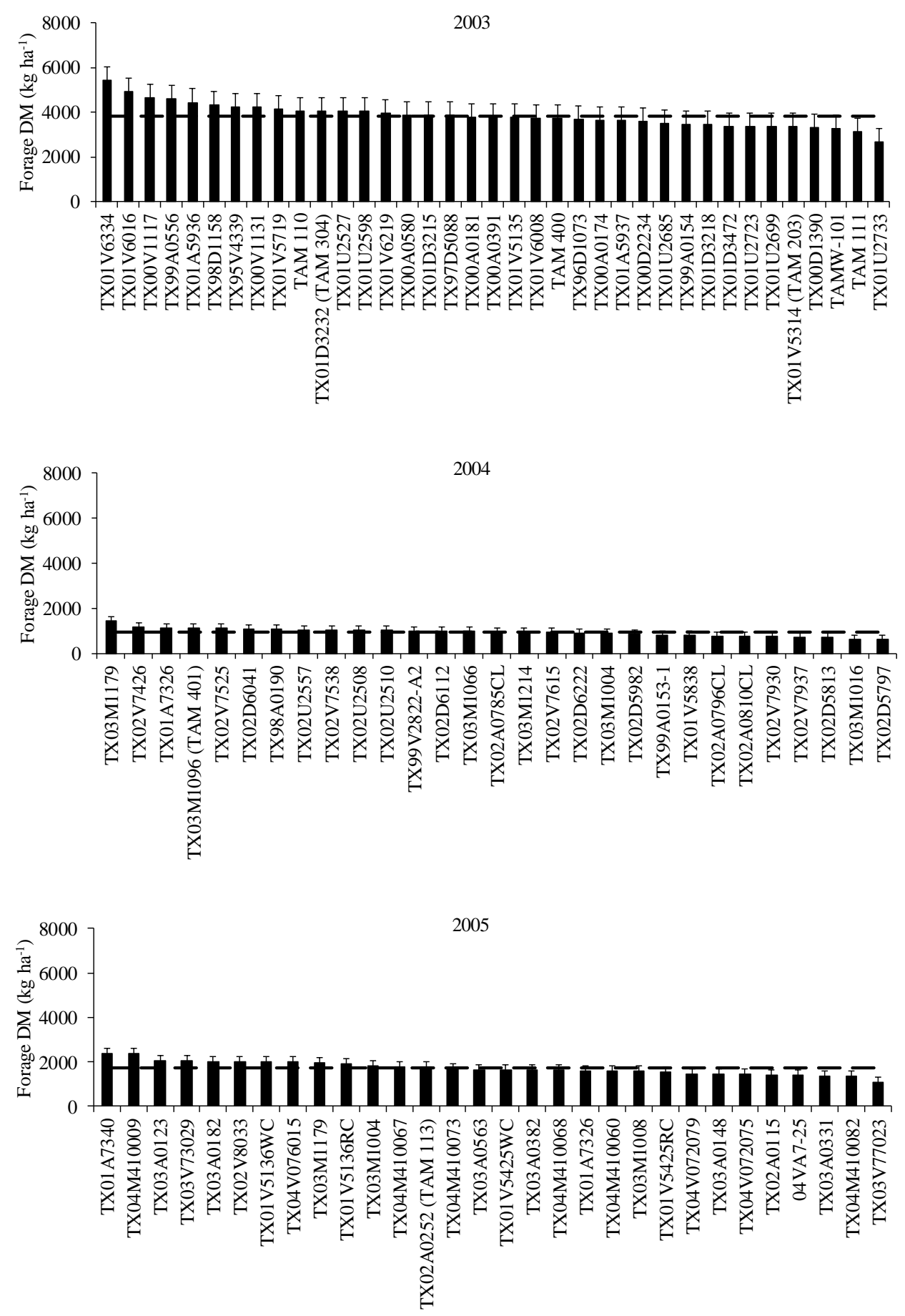

Fig. 2. Early-season (December) forage DM yield of wheat experimental lines in the TXE collection during 2003, 2004, and 2005 growing seasons. Bars indicate 1 s.e. Dotted line indicates early-season forage DM yield averaged over all wheat entries for a particular growing season. 

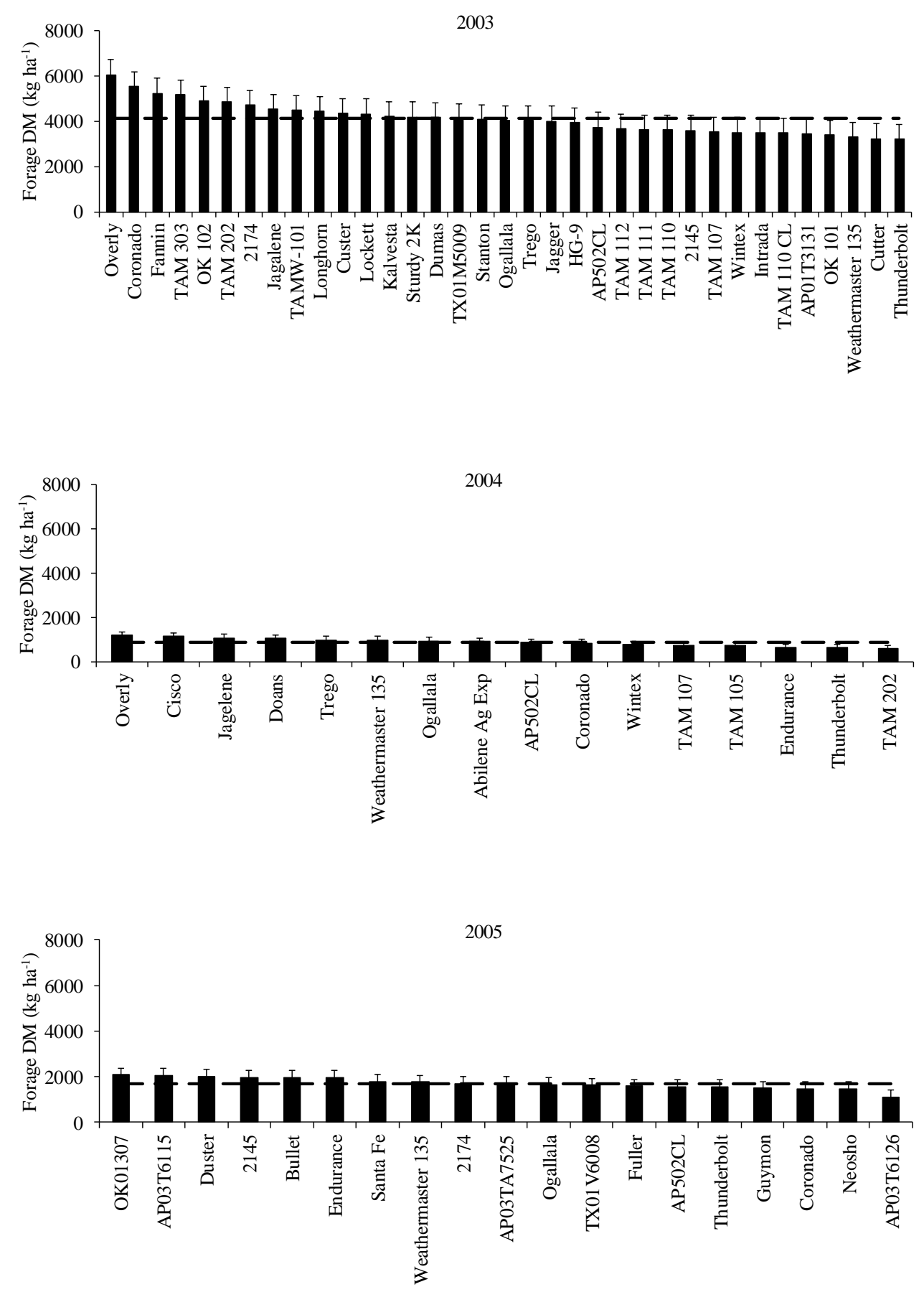

Fig. 3. Early-season (December) forage DM yield of wheat cultivars in the UVT collection during 2003, 2004, and 2005 growing seasons. Bars indicate 1 s.e. Dotted line indicates early-season forage DM yield averaged over all wheat entries for a particular growing season. 
Fig. 4. Early-season (December) forage DM of wheat cultivars and breeding lines evaluated in Experiment II during 2003, 2004, and 2005 growing seasons. Bars indicate 1 s.e. Dotted line indicates early-season forage DM yield averaged over all wheat entries for a particular growing season.

\section{Correlations Between Morphological Traits and Early-Season Forage Production}

The correlation coefficients showed significant relationships between the studied morphological traits and the early-season forage DM yield, both under supplemental irrigation in Experiment I during 2003 growing season and under rainfed conditions (Experiment I and Experiment II) during 2003, 2004, and 2005 growing seasons (Table 2 and Table 3). Except for 2004 growing season of Experiment II, early-season forage DM yield was highly positively correlated with tiller number (correlation coefficient values in the range of $0.36-0.81$ ) in 8 out of 9 times (89\%). The next morphological trait positively correlated with early-season forage DM was leaf length (correlation coefficient values in the range of $0.23-0.69$ ) in 7 out of 9 times $(78 \%)$. Leaf width was also positively correlated with early-season forage DM in 4 out of 9 times (44\%), with correlation coefficient values in the range 
of $0.21-0.41$. Specific leaf weight was negatively correlated with early-season forage DM in 5 out of 9 times (55\%), especially in seasons with adequate soil moisture availability (i.e., under supplemental irrigation in Experiment I during 2003 growing season and during the excessively wet 2004 growing season in both experiments), with correlation coefficient values ranging from -0.22 to -0.59 . Tiller number and SLW were negatively correlated with each other in 4 out of 9 times (44\%), with correlation coefficient values ranging from -0.46 to -0.61 .

Table 2. Correlation coefficients between early-season forage DM, leaf length, leaf width, SLW, and tiller number in wheat calculated from Experiment I during 2003-2005 growing seasons. Within a row, the upper value is for the TXE (experimental breeding lines) and the lower value is for the UVT (commercial cultivars) collections.

\begin{tabular}{|c|c|c|c|c|c|}
\hline $\begin{array}{l}\text { Growing } \\
\text { season }\end{array}$ & Trait & Forage DM & Leaf length & Leaf width & SLW \\
\hline \multirow[t]{8}{*}{2003} & Leaf length & $0.47^{* *}$ & & & \\
\hline & & $0.51^{* *}$ & & & \\
\hline & Leaf width & $0.21^{*}$ & $0.19^{*}$ & & \\
\hline & & $0.32^{* *}$ & $0.25^{* *}$ & & \\
\hline & SLW & $-0.22^{*}$ & $-0.26^{* *}$ & $-0.08^{\mathrm{ns}}$ & \\
\hline & & $-0.10^{\mathrm{ns}}$ & $-0.27^{* *}$ & $-0.12^{\mathrm{ns}}$ & \\
\hline & Tiller number & $0.36^{* *}$ & $0.07^{\mathrm{ns}}$ & $-0.15^{\mathrm{ns}}$ & $-0.02^{\mathrm{ns}}$ \\
\hline & & $0.46^{* *}$ & $0.09^{n s}$ & $-0.07^{\mathrm{ns}}$ & $-0.01^{\mathrm{ns}}$ \\
\hline \multirow[t]{6}{*}{2004} & Leaf length & $0.14^{\mathrm{ns}}$ & & & \\
\hline & & $0.35^{*}$ & & & \\
\hline & Leaf width & $0.19^{n s}$ & $0.56^{* *}$ & & \\
\hline & & $0.41^{*}$ & 0.38 * & & \\
\hline & SLW & $-0.59^{* *}$ & -0.17 ns & $0.21^{\mathrm{ns}}$ & \\
\hline & & $-0.44^{*}$ & $-0.42^{*}$ & $-0.35^{*}$ & \\
\hline
\end{tabular}




\begin{tabular}{|c|c|c|c|c|c|}
\hline & Tiller number & $0.72^{* \star}$ & $0.03^{n s}$ & $-0.09 \mathrm{~ns}$ & $-0.61^{* *}$ \\
\hline & & $0.64^{* *}$ & -0.10 ns & $-0.07^{\mathrm{ns}}$ & $-0.20^{\mathrm{ns}}$ \\
\hline \multirow[t]{5}{*}{2005} & Leaf length & $\begin{array}{l}0.38^{* *} \\
0.38^{* *}\end{array}$ & & & \\
\hline & Leaf width & $\begin{array}{l}0.12^{\mathrm{ns}} \\
0.18^{\mathrm{ns}}\end{array}$ & $\begin{array}{l}0.20^{n s} \\
0.33^{*}\end{array}$ & & \\
\hline & SLW & $\begin{array}{l}-0.06^{\mathrm{ns}} \\
-0.36^{\text {** }}\end{array}$ & $\begin{array}{l}-0.24^{*} \\
-0.22 \text { ns }\end{array}$ & $\begin{array}{l}0.06^{\mathrm{ns}} \\
-0.21^{\mathrm{ns}}\end{array}$ & \\
\hline & Tiller number & $0.67^{* *}$ & $0.11^{\mathrm{ns}}$ & $-0.12^{\mathrm{ns}}$ & $-0.61^{* *}$ \\
\hline & & $0.77^{* \star}$ & $0.20^{\mathrm{ns}}$ & $-0.09 \mathrm{~ns}$ & $-0.46^{* *}$ \\
\hline
\end{tabular}

$n \mathrm{~ns}^{*}$ and ${ }^{* *}$ : Not significant, significant at the $5 \%$ and $1 \%$ levels of probability, respectively.

Table 3. Correlation coefficients between early-season forage DM, leaf length, leaf width, specific leaf weight (SLW), and tiller number in wheat calculated from Experiment II during 2003-2005 growing seasons.

\begin{tabular}{|c|c|c|c|c|c|}
\hline $\begin{array}{l}\text { Growing } \\
\text { season }\end{array}$ & Trait & Forage DM & Leaf length & Leaf width & SLW \\
\hline \multirow[t]{4}{*}{2003} & Leaf length & -0.01 ns & & & \\
\hline & Leaf width & $0.22^{*}$ & $0.12^{\mathrm{ns}}$ & & \\
\hline & SLW & 0.09 ns & $-0.39^{* *}$ & $-0.53^{* *}$ & \\
\hline & Tiller number & $0.81^{\text {** }}$ & $0.10^{\mathrm{ns}}$ & 0.24 * & $0.05^{\mathrm{ns}}$ \\
\hline
\end{tabular}


Leaf length $\quad 0.23^{*}$

Leaf width

-0.08 ns

$0.53^{\text {* }}$

SLW

$-0.51^{* *}$

-0.22 *

$-0.16^{\mathrm{ns}}$

Tiller number

$-0.17^{\text {ns }}$

$0.01^{\text {ns }}$

$-0.07^{\mathrm{ns}}$

$0.13^{\text {ns }}$

2005

Leaf length

$0.69^{* *}$

Leaf width

$0.15^{\text {ns }}$

$0.11^{\text {ns }}$

SLW

$-0.17^{\text {ns }}$

$-0.03^{\text {ns }}$

$-0.18^{\text {ns }}$

Tiller number

$0.71^{* *}$

$0.31^{*}$

$-0.10^{\text {ns }}$

$-0.48^{* *}$

$\mathrm{ns}^{*}{ }^{*}$ and ${ }^{* *}$ : Not significant, significant at the $5 \%$ and $1 \%$ levels of probability, respectively.

Results of the stepwise regression variance analysis indicated that early-season forage DM yield was mainly determined by tiller number, both in Experiment I (Table 4) and Experiment II (Table 5). Depending on the growing season and experiment, tiller number explained $10-66 \%$, leaf length 5-26\%, leaf width $2-21 \%$, and SLW $2-26 \%$ variation in early-season forage DM yield.

Our results indicate that high tiller number, long and wide leaves, and low SLW are correlated with early-season forage DM yield. In grasses, selection for high yielding forage cultivars aims to increase both the number of tillers per plant and the biomass per tiller (Hanson and Carnahan, 1956). Tillering potential (and resulting earlyseason forage productivity) in wheat is determined by genetic makeup (Li et al., 2010), environmental factors such as light, rainfall and temperature, and certain management factors, i.e., mineral nutrition (Assuero and Tognetti, 2010). Among TXE wheat breeding lines evaluated in Experiment I and Experiment II, the highest tiller numbers were noted for TX01M5009, TX01V6008, TX01U2527, TX01A7326, TX99V2822-A2, TX02V8033, TX01V5425RC, TX04M410009, and TX97V5304 (Table 6). Among the UVT wheat cultivars evaluated in these experiments, Ogallala, Trego, Cisco, OK01307, Duster, 2145, OK 101, Intrada, TAM 112, Fannin, and TAM 303 
had the highest tiller number. Similar relationships between tiller number and forage DM yield were reported in perennial ryegrass (Lolium perenne L.) (Lazenby and Rogers, 1964; Thomson et al., 1973), tall fescue [Lolium arundinaceum (Schreb.) Darbysh.] (Nelson et al., 1977), and smooth bromegrass (Bromus inermis Leyss.) (Tan et al., 1979).

Table 4. Analysis of stepwise regression of early-season forage DM yield with tiller number, leaf length, leaf width, and SLW in Experiment I (TXE and UVT wheat collections) during three growing seasons.

\begin{tabular}{|c|c|c|c|c|c|c|}
\hline $\begin{array}{l}\text { Growing } \\
\text { season }\end{array}$ & Variable entered & Partial $R^{2}$ & Model $\mathrm{R}^{2}$ & $C(p)$ & F Value & $\operatorname{Pr}>\mathrm{F}$ \\
\hline \multirow[t]{8}{*}{2003} & TXE collection & & & & & \\
\hline & Leaf length & 0.2237 & 0.2237 & 25.75 & 34.00 & $<.0001$ \\
\hline & Tiller number & 0.1054 & 0.3290 & 8.51 & 18.37 & $<.0001$ \\
\hline & Leaf width & 0.0325 & 0.3615 & 4.58 & 5.90 & 0.0167 \\
\hline & UVT collection & & & & & \\
\hline & Tiller number & 0.2635 & 0.2635 & 15.93 & 64.63 & $<.0001$ \\
\hline & Leaf length & 0.2594 & 0.5229 & 85.71 & 41.33 & $<.0001$ \\
\hline & Leaf width & 0.0494 & 0.5724 & 4.47 & 13.41 & 0.0004 \\
\hline \multirow[t]{8}{*}{2004} & TXE collection & & & & & \\
\hline & Tiller number & 0.5192 & 0.5192 & 19.41 & 62.64 & $<.0001$ \\
\hline & Leaf width & 0.0681 & 0.5873 & 10.73 & 9.40 & 0.0033 \\
\hline & SLW & 0.0620 & 0.6493 & 3.00 & 9.91 & 0.0026 \\
\hline & UV干 collection & & & & & \\
\hline & Tiller number & 0.4102 & 0.4102 & 24.37 & 20.86 & $<.0001$ \\
\hline & Leaf width & 0.2086 & 0.6188 & 7.85 & 15.87 & 0.0004 \\
\hline & Leaf length & 0.0721 & 0.6909 & 3.45 & 6.53 & 0.0163 \\
\hline \multirow[t]{8}{*}{2005} & TXE collection & & & & & \\
\hline & Tiller number & 0.4535 & 0.4535 & 42.61 & 73.02 & $<.0001$ \\
\hline & Leaf length & 0.0954 & 0.5489 & 22.16 & 18.40 & $<.0001$ \\
\hline & SLW & 0.0634 & 0.6123 & 9.25 & 14.06 & 0.0003 \\
\hline & Leaf width & 0.0266 & 0.6388 & 5.00 & 6.25 & 0.0143 \\
\hline & UVA collection & & & & & \\
\hline & Tiller number & 0.5995 & 0.5995 & 7.44 & 82.32 & $<.0001$ \\
\hline & Leaf length & 0.0527 & 0.6521 & 1.49 & 8.18 & 0.0060 \\
\hline
\end{tabular}

Table 5. Analysis of stepwise regression of early-season forage DM yield with tiller number, leaf length, leaf width, and SLW in wheat in Experiment II during three growing seasons.

\begin{tabular}{llccccc}
\hline $\begin{array}{l}\text { Growing } \\
\text { season }\end{array}$ & Variable entered & Partial $R^{2}$ & Model $R^{2}$ & $C(p)$ & $F$ Value & Pr $>F$ \\
\hline 2003 & Tiller number & 0.6613 & 0.6613 & 0.43 & 160.11 & $<.0001$ \\
2004 & SLW & 0.2615 & 0.2615 & 6.56 & 30.10 & $<.0001$
\end{tabular}




\begin{tabular}{|c|c|c|c|c|c|c|}
\hline \multirow[t]{4}{*}{2005} & Tiller number & 0.5457 & 0.5457 & 66.01 & 87.70 & $<.0001$ \\
\hline & Leaf length & 0.1810 & 0.7267 & 13.42 & 47.69 & $<.0001$ \\
\hline & Leaf width & 0.0225 & 0.7492 & 8.64 & 6.37 & 0.0138 \\
\hline & SLW & 0.0187 & 0.7679 & 5.00 & 5.64 & 0.0203 \\
\hline
\end{tabular}

Table 6. Wheat entries with highest and lowest tiller numbers in Experiment I and II during 2003-2005 growing seasons.

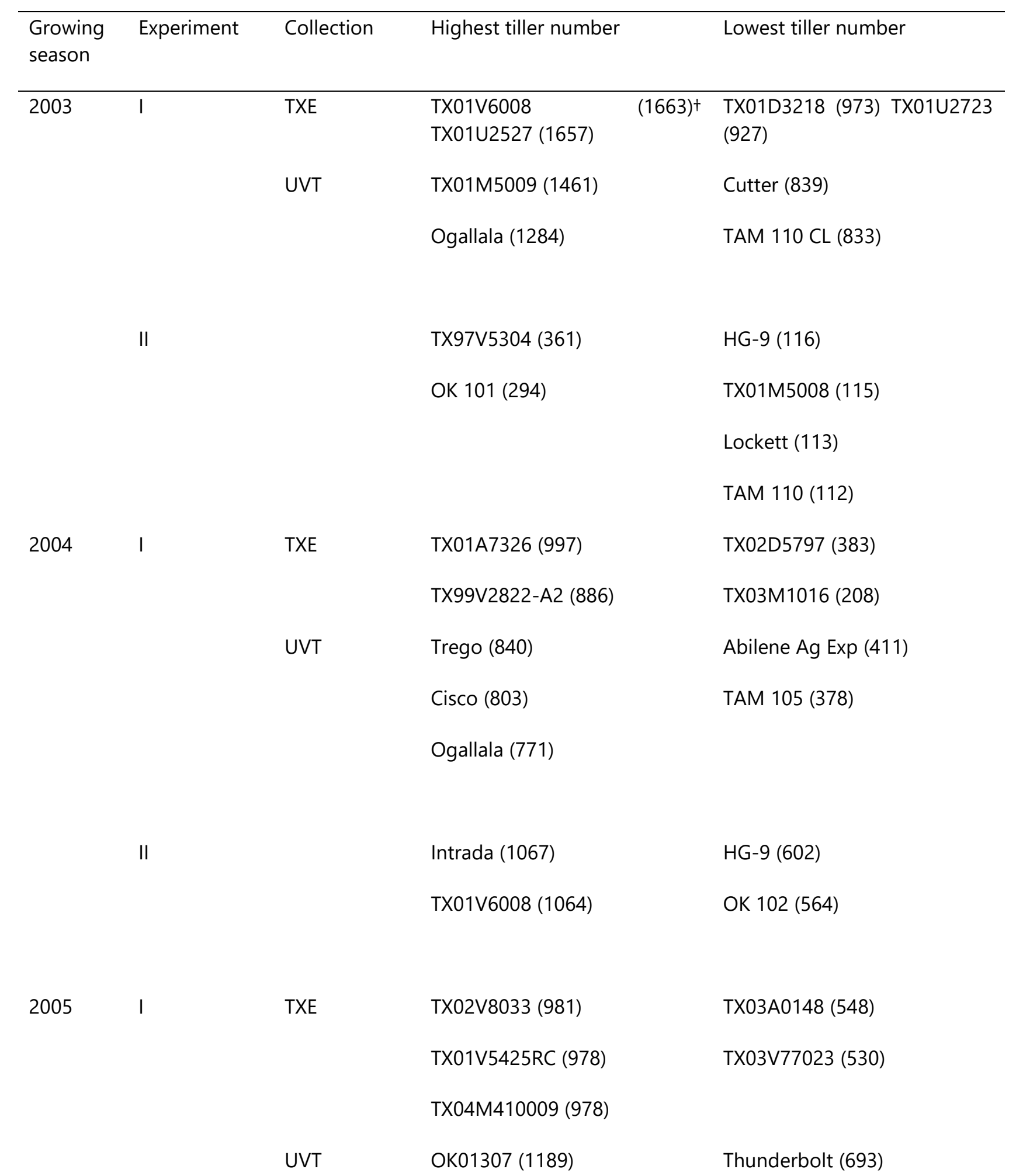


Duster (1022)

AP03T6126 (615)

$2145(1022)$

II

TAM $112(1341)$

Fannin (1185)

TAM $303(1030)$
TAM 110 (615)

Overley (589)

+ Numbers in parentheses indicate tiller number $0.5 \mathrm{~m}^{-2}$.

Leaf length and leaf width were also closely correlated with early-season forage productivity in our studies. The longest leaves were produced by TXE breeding lines TX03M1179, TX01A7340, TX01V6016, TX04M410009, TX04V072075, TX02V7937, TX99A0556, TX01D3215, TX00V1117, TX02U2557, TX02D5797, TX03V76009, and TX99A0153-1 (Table 7). Among wheat cultivars in the UVT collection, the longest leaves were produced by HG9, Duster, Weather master 135, Endurance, Fannin, Abilene Ag Exp, Wintex, Longhorn, and Stanton. Among TXE wheat breeding lines, the widest leaves were produced by TX04M410067, TX02A0115, TX01A7340, TX03A0382, TX03M1179, TX03V73029, TX01D3232 (TAM 304), TX03M1016, TX02U2557, TX02D6112, TX01M5009, TX01A5936, TX01V5719, and TX01V6334 (Table 8). Cultivars with the widest leaves in the UVT collection were Dumas, Cutter, Weather master 135, Guymon, 2145, HG-9, Overly, TAM 110, Longhorn, Abilene Ag Exp, Doans, and Jagelene. Several studies have indicated a negative correlation between leaf elongation rate and tillering in tall fescue (Nelson et al., 1977; Zarrough et al., 1984) and perennial ryegrass (Gautier et al., 1999). Thus, it may be difficult to combine high tillering potential and leaf elongation rate in one wheat cultivar. In our studies, we generally did not observe significant correlations between leaf length or leaf width and tiller number in wheat. Two exceptions were found in Experiment II during 2003 growing season (leaf width) and 2005 growing season (leaf length).

Table 7. Wheat entries with longest and shortest leaves in Experiment I and II during 2003-2005 growing seasons.

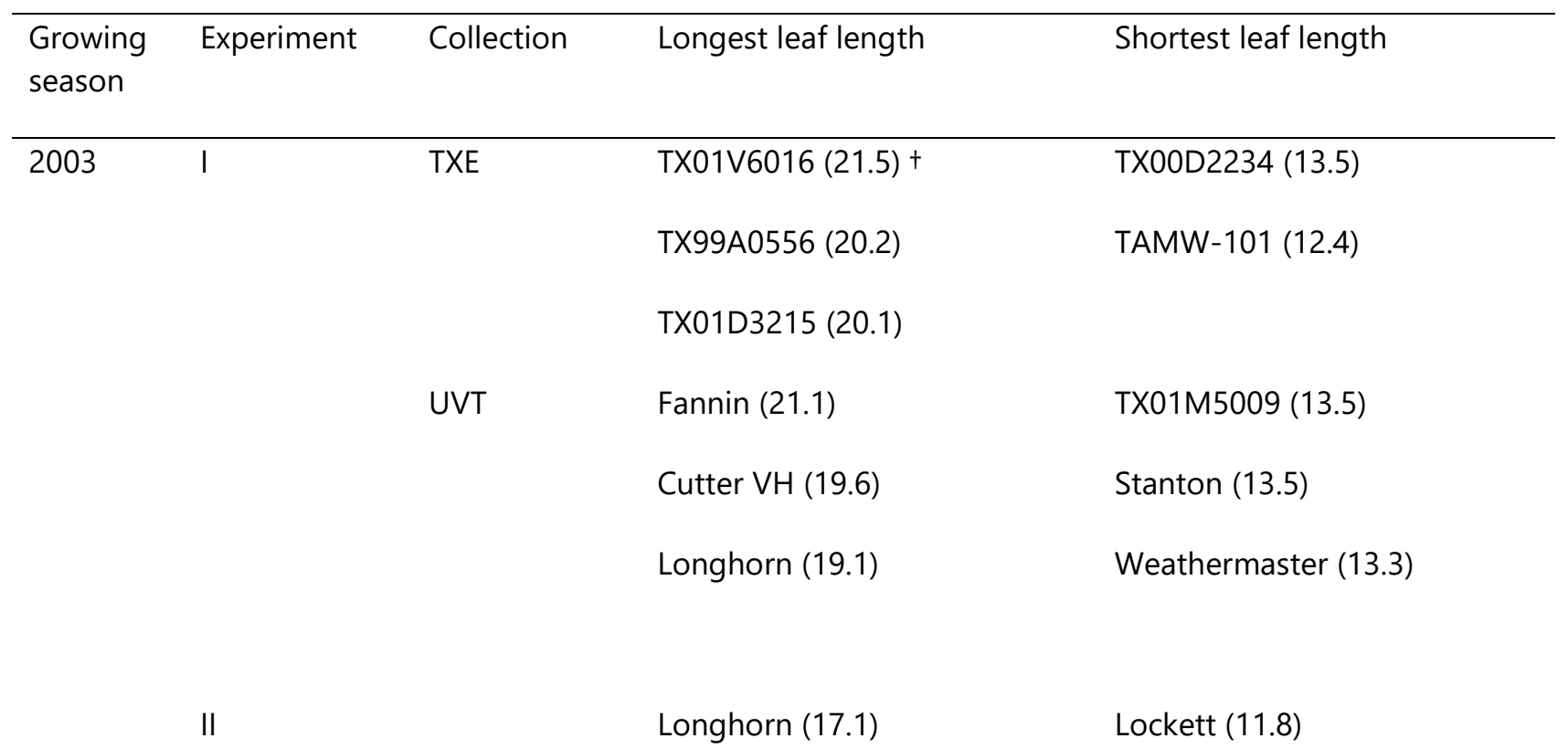


Stanton (15.4)

TX01M5008 (11.8)

TX96D1073 (11.7)

TAM 302 (11.5)

2004

TXE

TX02V7937 (21.1)

TX02U2557 (19.5)

TX02A0796CL (14.9)

TX99V2822-A2 (14.2)

TX02D5797 (19.5)

UVT

Abilene Ag Exp (20.9)

Wintex (20.6)

Weathermaster (19.9)

II

HG-9 (22.1)

TX00V1117 (19.8)

TXE

TX03M1179 (22.0)

TX01A7340 (21.6)

TX04M410009 (21.2)

TX04V072075 (21.2)

UVT

Duster (21.8)

Weathermaster (21.7)

Endurance (21.3)

II

TX03V76009 (19.2)

Fannin (18.8)

TX99A0153-1 (18.8)

TX00V1117 (18.7)
TAM 112 (13.9)

Stanton (13.2)

TX04M410073 (16.2)

TX03A0563 (16.1)

Thunderbolt (16.8)

Santa Fe (16.6)

AP502CL (16.5)

Neosho (16.4)

TAM 111 (14.4)

Cutter (14.3)

TAM-W101 (13.5)

†Numbers in parentheses indicate average leaf length (cm). 
Table 8. Wheat entries with widest and narrowest leaves in Experiment I and II during 2003-2005 growing seasons.

\begin{tabular}{|c|c|c|c|c|}
\hline $\begin{array}{l}\text { Growing } \\
\text { season }\end{array}$ & Experiment & Collection & Widest leaf width & Narrowest leaf width \\
\hline \multirow[t]{9}{*}{2003} & 1 & TXE & TX01A5936 (0.35) + & TX01U2733 (0.23) \\
\hline & & & TX01V6334 (0.32) & TX00V1131 (0.23) \\
\hline & & & TX01V5719 (0.32) & TX01U2699 (0.23) \\
\hline & & UVT & Dumas $(0.34)$ & Ogallala (0.23) \\
\hline & & & Cutter ML (0.33) & Thunderbolt (0.22) \\
\hline & & & Overly $(0.32)$ & Jagger $(0.21)$ \\
\hline & ॥ & & TX01M5009 (0.48) & $2137(0.39)$ \\
\hline & & & TAM $110(0.48)$ & TX97D5088 (0.38) \\
\hline & & & Longhorn (0.48) & TX99A0155 (0.37) \\
\hline \multirow[t]{10}{*}{2004} & I & TXE & TX03M1016 (0.49) & TX02D5982 (0.33) \\
\hline & & & TX02U2557 (0.48) & TX02D5813 (0.33) \\
\hline & & & TX02D6112 (0.46) & TX03M1004 (0.31) \\
\hline & & UVT & Overly $(0.49)$ & Thunderbolt (0.35) \\
\hline & & & Abilene Ag $\operatorname{Exp}(0.44)$ & TAM $107(0.33)$ \\
\hline & & & Doans $(0.44)$ & Endurance $(0.28)$ \\
\hline & & & Jagelene $(0.44)$ & \\
\hline & II & & $2145(0.55)$ & TX01U2598 (0.35) \\
\hline & & & Dumas (0.55) & Fannin $(0.34)$ \\
\hline & & & HG-9 (0.51) & TX01V5314 (TAM 203) (0.30) \\
\hline 2005 & 1 & TXE & TX04M410067 (0.66) & TX03A0331 (0.41) \\
\hline
\end{tabular}


TX02A0115 (0.64)

TX01A7340 (0.62)

TX03A0382 (0.62)

TX03M1179 (0.62)

TX03V73029 (0.62)

UVT

Weathermaster 135 (0.56)

Guymon (0.55)

Dumas (0.62)

TX01D3232 (TAM 304) (0.62)

Cutter (0.57)
TX01V5425RC (0.41)

Fuller (0.40)

SantaFe (0.38)

TAM $111(0.43)$

TX03M1096 (TAM 401) (0.43)

Fannin (0.42)

+Numbers in parentheses indicate average leaf length $(\mathrm{cm})$.

The lowest SLW was noted for TX02V7426, TX98A0190, TX03M1179, TX02U2510, TX03M1008, TX01V5425WC, and TX00D1390 in the TXE collection (Table 9). Among the UVT wheat cultivars, HG-9, 2174, Lockett, TAM 400, Cisco, Abilene Ag Exp, Weathermaster 135, AP502CL, Wintex, Stanton, Intrada, Jagger, and TAM 110 had the lowest SLW. Specific leaf weight (an inverse of specific leaf area) has been associated with relative growth rate (RGR) in numerous non-woody $C_{3}$ species (Poorter and Remkes, 1990). Fast growing species with a high RGR express lower SLW (or higher specific leaf area, SLA) than slow growing species with high SLW. Results of our studies suggest that a relationship between SLW and growth rate occurs also in wheat, i.e., low SLW is associated with high tiller number and forage production in the early growing season. Specific leaf weight may affect forage DM accumulation in wheat because of a positive association between $\mathrm{SLW}$ and net $\mathrm{CO}_{2}$ exchange rate per unit leaf area (Khan and Tsunoda, 1970; Delaney and Dobrenz, 1976; Dornhoff and Shible, 1976) and a negative association between SLW and the rate of leaf area expansion (Rawson et al., 1987; Hay, 1990; Solhaug, 1991). The negative correlation between SLW and early-season forage production, however, varied among seasons, suggesting that environmental factors may have played more significant role in affecting SLW (and early-season forage DM yield) than wheat genotype effects. Similar results were reported by López-Castañeda et al., (1995) and Rebetzke et al., (2004) who found that environment had the largest influence on SLW both directly and through interactions with wheat genotypes.

Table 9. Wheat entries with highest and lowest SLW in Experiment I and II during 2003-2005 growing seasons.

\begin{tabular}{lllll}
\hline $\begin{array}{l}\text { Growing } \\
\text { season }\end{array}$ & Experiment & Collection & Highest SLW & Lowest SLW \\
\hline 2003 & $\mathrm{I}$ & TXE & TX00D2234 (0.0075) ${ }^{\dagger}$ & TX01U2723 (0.0058) \\
& & TAMW-101 (0.0074) & TX01V6016 (0.0054) \\
& & & TX00A0391 (0.0054) \\
& UVT & Kalvesta (0.0069) & Cutter H (0.0053)
\end{tabular}


Trego (0.0068)

II

2004

I

II

UVT

TXE

TXE

UVT
TAM 202 (0.0047)

Thunderbolt (0.0047)

TAM 107 (0.0046)

Coronado (0.0046)

TX01V6008 (0.0047)

Stanton (0.0046)

TX03V73029 (0.0058)

TX01V5136WC (0.0057)

TX97V5304 (0.0084)

$2137(0.0074)$

TX02A0785CL (0.0049)

TX02D5813 (0.0048)

AP502CL (0.0057)
Cutter $\mathrm{MH}$ (0.0053)

TAM 400 (0.0049)

Jagger (0.0048)

TAM $110(0.0048)$

Stanton (0.0046)

Intrada (0.0046)

TX98A0190 (0.0040)

TX03M1179 (0.0040)

TX02U2510 (0.0040)

TX02V7426 (0.0038)

Abilene Ag Exp (0.0042)

Weathermaster (0.0042)

AP502CL (0.0042)

Wintex (0.0042)

Cisco (0.0038)

$2174(0.0036)$

Lockett (0.0036)

TAM 400 (0.0036)

HG-9 (0.0034)

TX03M1179 (0.0047)

TX01V5425WC (0.0046)

TX03M1008 (0.0045)

$2174(0.0044)$ 
Bullet (0.0055)

TAM 110 (0.0058)

TAM 111 (0.0057)
Weathermaster 135 (0.0044)

TX00D1390 (0.0047)

HG-9 (0.0047)

Sturdy2K (0.0041)

† Numbers in parentheses indicate SLW $\left(\mathrm{g} \mathrm{cm}^{-2}\right)$.

\section{CONCLUSIONS}

Among the wheat breeding lines and cultivars evaluated in our studies, there was no single one with all four morphological traits (high tiller number, long and wide leaves, and low SLW) combined to maximize early-season forage DM yield. Tiller number and leaf area are considered important traits for the improvement of forage DM productivity in wheat (Kim et al., 2016). Several wheat entries expressed high tillering potential and long or wide leaves, including Fannin, Duster (Edwards et al., 2012), TX01M5009, and TX04M410009. Other wheat entries expressed long and/or wide leaves and low SLW, including Abilene Ag Exp, Cutter, HG-9, TAM 110, TX01V6016, TX03M1179, and Weathermaster 135. Most of these cultivars/breeding lines have been recommended for dualpurpose use; thus, the morphological traits evaluated in our studies were desirable for selection of wheat with improved forage productivity. It is also interesting to note that TX01M5009 and TAM 112 (Rudd et al., 2014) were parents of the recently released forage and dual-purpose wheat cultivar, TAM 204 (Ledbetter, 2014), indicating that the morphological traits correlated with high early-season forage DM yield may be heritable.

\section{Conflict of Interest Statement}

The authors declare no conflict of interest in conducting these studies.

\section{Funding Sources}

These studies were supported by the Texas Wheat Producers Board.

\section{REFERENCES}

1. Assuero, S.G., and J.A. Tognetti. 2010. Tillering regulation by endogenous and environmental factors and its agricultural management. Americas J. Plant Sci. Biotech. 4:35-48.

2. Atkins, I.M., Merkle, O.G., and P.E. Pawlisch. 1969. Visual estimates and clipping plot size for evaluating the forage potential of small grain varieties. Agron. J. 61:88-91.

3. Bean, B. 2006. 2006 Wheat variety trials conducted in the Texas and New Mexico High Plains. Texas Cooperative Extension. Texas A\&M Univ., College Station. http://agrilife.org/amarillo/files/2010/11/2006 wheat annual summary.pdf (accessed 12 Nov. 2018).

4. Bean, B., Morgan, G., and J. Rudd. 2005. 2004-2005 Description of wheat varieties in uniform regional and county trials. Texas Cooperative Extension. Texas A\&M Univ., College Station. http://agrilife.org/amarillo/files/2010/11/2005WheatVarietyDescriptions.pdf (accessed 12 Nov. 2018).

5. Delaney, R.H., and A.K Dobrenz. 1976. Morphological and anatomical features of alfalfa leaves are related to $\mathrm{CO}_{2}$ exchange. Crop Sci. 14:444-447. 
6. Dornhoff, G.M., and R. Shibles. 1976. Leaf morphology and anatomy in relation to $\mathrm{CO}_{2}$ exchange rate of soybean leaves. Crop Sci. 16: 377-381.

7. Edwards, J., Austin, R., Carver, B., Tipton, B., Butchee, D., and J. Sanders. 2008. Fall forage production by winter wheat varieties in Oklahoma. Production Technol. 20 (1). Oklahoma State Univ., Stillwater, OK. http://croptrials.okstate.edu/wheat/forage-yield/08-07Fall\%20Forage\%20Production\%20in\%202007.pdf (accessed 12 Nov. 2018).

8. Edwards, J.T., Hunger, R.M., Smith, E.L., Horn, G.W., Chen, M.-S., Yan, L., Bai, G., Bowden, R.L., Klatt, A.R., Rayas-Duarte, P., Osburn, R.D., Giles, K.L., Kolmer, J.A., Jin, Y., Porter, D.R., Seabourn, B.W., Bayles, M.B., and B.F. Carver. 2012. 'Duster' wheat: A durable, dual-purpose cultivar adapted to the Southern Great Plains of the USA. J. Plant Registr. 6:37-48.

9. Gautier, H., Varlet-Grancher, C., and L. Hazard. 1999. Tillering responses to the light environment and to defoliation in populations of perennial ryegrass (Lolium perenne L.) selected for contrasting leaf length. Ann. Bot. 83:423-429.

10. Hanson, A.A., and H.L. Carnahan. 1956. Breeding perennial forage grasses. Tech. Bull. No. 1145. United States Department of Agriculture. Agricultural Research Service, Washington, D.C.

11. Hay, R.K.M. 1990. Tansley Review No. 26. The influence of photoperiod on the dry matter production of grasses and cereals. New Phytol. 116:233-254.

12. Horn, G.W., Raun, W.R., Highfill, G.A., Bowen, C., and R.K. Boman. 1993. Evaluation of bloat potential of cattle as affected by $\mathrm{N}$ and $\mathrm{K}$ fertilization in continuous winter wheat. Animal Science Research Report P933. pp. 269-274. Oklahoma State Univ., Stillwater, OK. http://www.beefextension.com/research reports/1993rr/93 46.pdf (accessed 12 Nov. 2018).

13. Hossain, I., Epplin, F.M., Horn, G.W., and E.G. Krenzer, Jr. 2004. Wheat production practices used by Oklahoma grain and livestock producers. Oklahoma Agric. Exp. Stn. Publication B-818. Oklahoma State Univ., Stillwater, OK. http://pods.dasnr.okstate.edu/docushare/dsweb/Get/Rendition-1928/unknown (accessed 12 Nov. 2018).

14. Khan, M.A., and S. Tsunoda. 1970. Differences in leaf photosynthesis and leaf transpiration rates among six commercial wheat varieties of West Pakistan. Japanese J. Plant Breeding 20:344-350.

15. Kim, K.S., Anderson, J.D., Newell, M.A., Grogan, S.M., Byrne, P.F., Baenziger, P.S., and T.J. Butler. 2016. Genetic diversity of Great Plains hard winter wheat germplasm for forage. Crop Sci. 56:2297-2305.

16. Krenzer, E.G., Jr, Tarrant, A.R., Bernardo, D.J., and G.W. Horn. 1996. An economic evaluation of wheat cultivars based on grain and forage production. J. Prod. Agric. 9:66-73.

17. Krenzer, E.G., Jr, Thompson, J.D. and B.F. Carver. 1992. Partitioning of genotype x environment interactions of winter wheat forage yield. Crop Sci. 32:1143-1147.

18. Lantican, M.A., Dubin, H.J., and M.L. Moris. 2005. Impacts of international wheat breeding research in the developing world, 1988-2002. CIMMYT, Mexico, DF. http://cuke.hort.ncsu.edu/cucurbit/wehner/521/hs521readings/WhtBrdCIMMYT.pdf (accessed 12 Nov. 2018).

19. Lazenby, A., and H.H. Rogers. 1964. Selection criteria in grass breeding. II. Effect, on Lolium perenne L., of differences in population density, variety and available moisture. J. Agric. Sci. 62:285-298. 
20. Ledbetter, K. 2014. Texas A\&M AgriLife program to release two new wheat varieties. Texas A\&M AgriLife - Ag News, Texas A\&M Univ., College Station, TX. http://today.agrilife.org/2014/05/21/texas-am-agrilifeprogram-to-release-two-new-wheat-varieties (accessed 12 Nov. 2018).

21. Li, Z., Peng, T., Xie, Q., Han, S., and J. Tian. 2010. Mapping of QTL for tiller number at different stages of growth in wheat using double haploid and immortalized F2 populations. J. Genetics 89:409-415.

22. López-Castañeda, C., Richards, R.A., and G.D. Farquhar. 1995. Variation in early vigor between wheat and barley. Crop Sci. 35:472-479.

23. MacKown, C.T., Carver, B.R., and T.J. Edwards. 2008. Occurrence of condensed tannins in wheat and feasibility for reducing pasture bloat. Crop Sci. 48:2470-2480. doi:10.2135/cropsci2008.01.0020

24. Nelson, C.J., Asay, K.H., and D.A Sleper. 1977. Mechanisms of canopy development of tall fescue genotypes. Crop Sci. 17:449-452.

25. Pfeiffer, W.H. 1992. Triticale improvement strategies at CIMMYT: exploiting adaptive patterns and enduse orientation. In: D.G. Tanner and W. Mwangi, editors, Proceedings of The Seventh Regional Wheat Workshop for Eastern, Central and Southern Africa, Nakuru, Kenya. 16-19 September 1991. CIMMYT, Mexico, D.F., Mexico. pp. 73-85.

26. Pinchak, W.E., Worral, W.D., Caldwell, S.P., Hunt, L.J., Worral, H.J., and M. Conoly. 1996. Interrelationships of forage and steer growth dynamics on wheat pasture. J. Range Manage. 49:126-130. doi:10.2307/4002681

27. Poorter, $\mathrm{H}_{\text {., }}$ and C. Remkes. 1990. Leaf area ratio and net assimilation rate of 24 wild species differing in relative growth rate. Oecologia 83:553-559.

28. Rajaram, S., and G.P. Hettel. 1995. Wheat breeding at CIMMYT: Commemorating 50 years of research in Mexico for global wheat improvement. Wheat Special Report No. 29. CIMMYT, Mexico, D.F., Mexico.

29. Raushel, F. 2011. List of profiles by soil order. Texas A\&M Univ., College Station, TX. http://soildata.tamu.edu/order.htm (accessed 12 Nov. 2018).

30. Rawson, H.M., Gardner, P.A., amd M.J. Long. 1987. Sources of variation in specific leaf area in wheat grown at high temperature. Aust. J. Plant Physiol. 14:287-289.

31. Rebetzke, G.J., Botwright, T.L., Moore, C.S., Richards, R.A., and A.G. Condon. 2004. Genotypic variation in specific leaf area for genetic improvement of early vigour in wheat. Field Crops Res. 88:179-189.

32. Rudd, J.C., Devkota, R.N., Baker, J.A., Peterson, G.L., Lazar, M.D., Bean, B., Worrall, D., Baughman, T., Marshall, D., Sutton, R., Rooney, L.W., Nelson, L.R., Fritz, A.K., Weng, Y., Morgan, G.D., and B.W. Seabourn. 2014. 'TAM 112' Wheat: A greenbug and wheat curl mite resistant cultivar adapted to the dryland production system in the Southern High Plains. J. Plant Registr. 8:291-297.

33. Rudd, J.C., Devkota, R.N., Fritz, A.K., Baker, J.A., Obert, D., Worrall, D., Sutton, R., Rooney, L.W., Nelson, L.R., Weng, Y. Morgan. G.D., Bean, B., Ibrahim, A., Klatt, A., Bowden, R., Graybosch, R., Jin, Y., and B.W. Seabourn. 2012. Registration of TAM 401 wheat. J. Plant Registr. 6:60-65.

34. SAS Institute. 1999. SAS user's guide. Version 8.0. SAS Institute, Cary, NC.

35. Solhaug, K.A. 1991. Influence of photoperiod and temperature on dry matter production and chlorophyll in temperate grasses. Norwegian J. Agric. Sci. 5:365-383. 
36. Tan, W., Tan, G., and P.D. Walton. 1979. Genotype x environment interactions in smooth bromegrass. II. Morphological characters and their associations with forage yield. Can. J. Genet. Cytol. 21:73-80.

37. Thomson, A.J., Wright, A.J., and H.H. Rogers. 1973. Studies on the agronomy, genetics and interrelationships of yield and its morphological components in a diallel set of families of Lolium perenne L. J. Agric. Sci. 80:511-520.

38. Ud-Din, N., Carver, B.F., and E.G. Krenzer. 1993. Visual selection for forage yield in winter wheat. Crop Sci. 33:41-45.

39. Worrall, W.D., Caldwell, S.P., Marshall, D.S., McDaniel, M.E., Serna Saldivar, S., and M.D. Lazar. 1995. Registration of 'TAM-202' wheat. Crop Sci. 35:1224-1225.

40. Zarrough, K.M., Nelson, C.J., and D.A. Sleper. 1984. Interrelationships between rates of leaf appearance and tillering in selected tall fescue populations. Crop Sci. 24:565-569. 